\title{
METAL OPERATOR MINING FACTS - 2005
}

\section{Mining Operations}

In 2005, a total of $263 \mathrm{~m}$ etal mining operations reported employment to the Mine $\mathrm{S}$ afety and $\mathrm{H}$ ealth Administration (MSHA). Metal $\mathrm{m}$ ines were the smallest mining commodity sector, comprising $1.8 \%$ of all mining operations.

- Gold $m$ ines com prised $46.0 \%(n=121)$ of all metal mining operations. Other common types of $m$ etal mines were iron ore $(n=32 ; 12.2 \%)$, copper ore $(\mathrm{n}=31 ; 11.8 \%)$, and lead and/or zinc ore $(n=16 ; 6.1 \%)$.

- Nevada had the largest num ber of $m$ etal $m$ ines $(\mathrm{n}=52 ; 19.8 \%)$, followe d by Alaska $(\mathrm{n}=27$; $10.3 \%)$.

\section{Employees}

A total of 26,442 employees, ${ }^{1}$ corresponding to 27,773 full-time equivalent (FTE) ${ }^{2}$ employees, were reported by metal mine operators.

- Within the $\mathrm{m}$ ining sectors, ${ }^{3}$ metal mine operator employees accounted for $9.6 \%$ of all em ployee hours reported to MSHA.

- Metal operator employee hours were reported for both underg round (15.1\%) and surface $(84.9 \%)$ work locations. ${ }^{4}$

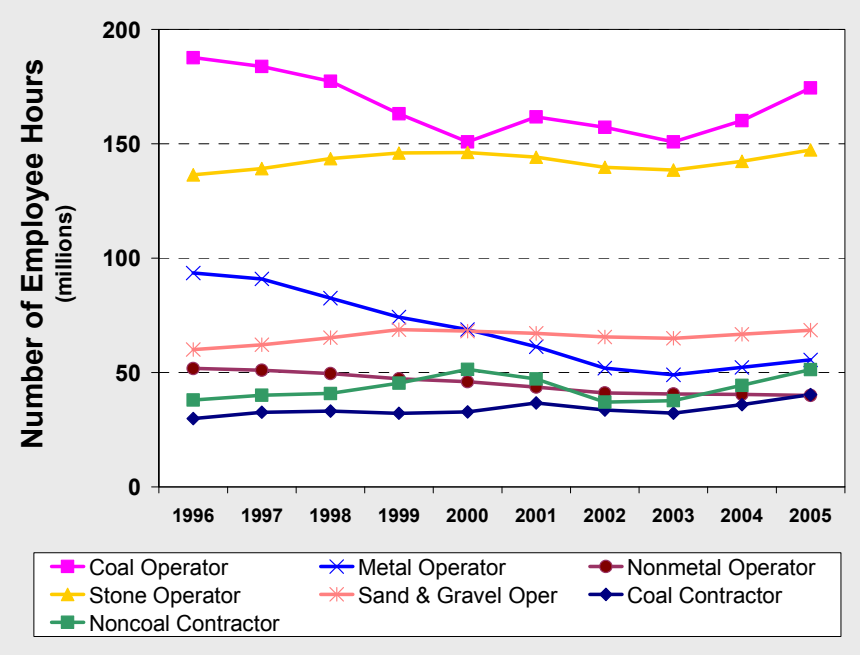

\section{Fatalities}

Five occupational fatali ties occurred a mong m etal mine operator em ployees in 2005 , com pared to two fatalities in 2004.

- The $\mathrm{m}$ etal $\mathrm{m}$ ine operator fatality rate was 18.0 fatalities per 100,000 FTE employees.

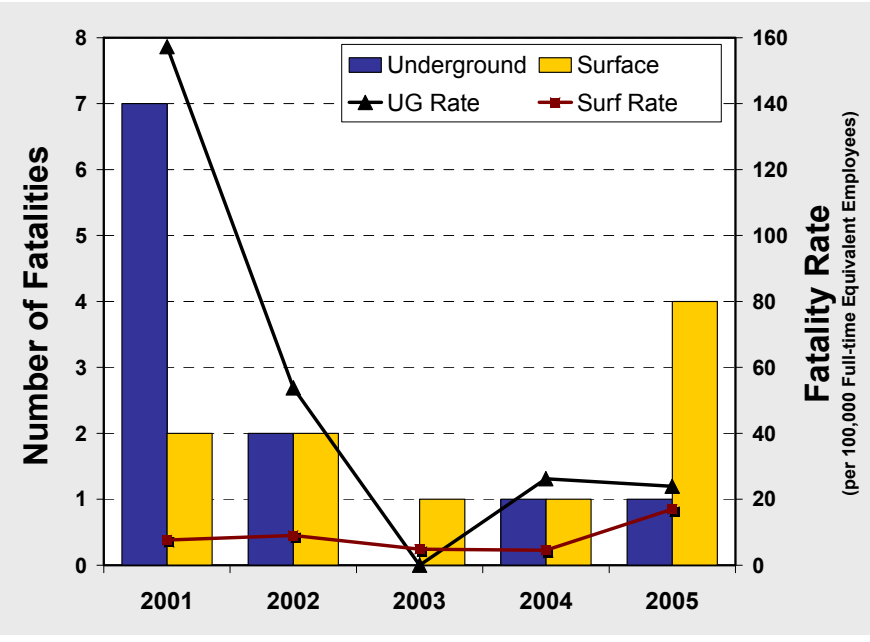

Nonfatal Lost-time Injuries

There were 678 nonfatal lost -time injuri es (154 at underground and 524 at surface work locations) among metal operator employees occurring at a rate of 2.4 injuries per $100 \mathrm{FTE}$ e mployees. A total of 25,843 days lost ${ }^{5} \mathrm{f}$ rom work resulted $\mathrm{f}$ rom these injuries.

- The underground nonfatal lo st-time injury rate was greater than th e surface inju ry rate (3.7 vs. 2.2 per 100 FTE workers).

- The most frequent classi fication of nonfatal losttime injuries $\mathrm{f}$ or $\mathrm{m}$ etal opera tor em ployees involved handling materials $(n=231 ; 34.1 \%)$.

- Sprains and str ains we re the $m$ ost $f$ requently reported nature of injury $(n=347 ; 51.2 \%)$.

- The back w as the most frequently reported body part injured $(\mathrm{n}=116 ; 17.1 \%)$ and accounted for 3,492 days lost from work.

\section{Distribution of Nonfatal Lost-time Injuries} by Accident Class, 2001-2005

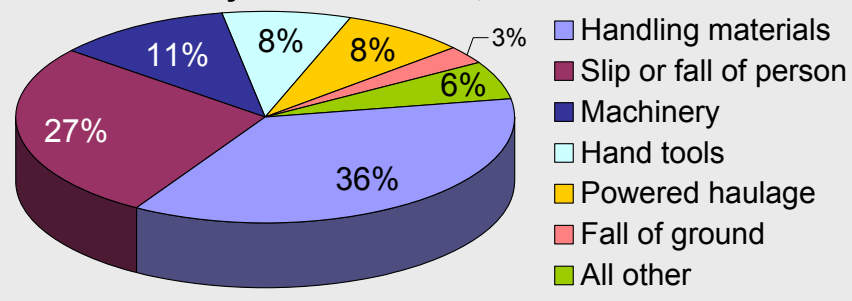

Note: "Fall of ground" includes MSHA's Accident/Injury/lllness classification for fall of face, rib, pillar side, or highwall (from in place); fall of roof, back, or brow (from in place); and underground machinery cases when the source of injury was caving rock, coal, ore, or waste.

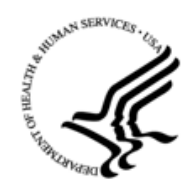




\begin{tabular}{|c|c|c|c|c|c|c|}
\hline \multicolumn{7}{|c|}{ Mining Characteristics, 2005} \\
\hline $\begin{array}{l}\text { Commodity and } \\
\text { Type of Employer }\end{array}$ & $\begin{array}{l}\text { No. of } \\
\text { Mines }\end{array}$ & $\begin{array}{l}\text { No. of } \\
\text { Companies }\end{array}$ & $\begin{array}{l}\text { No. of } \\
\text { Employees }\end{array}$ & $\begin{array}{l}\text { No. of FTE } \\
\text { Employees }\end{array}$ & $\begin{array}{l}\text { Fatality } \\
\text { Rate }\end{array}$ & $\begin{array}{l}\text { Nonfatal } \\
\text { Lost-time } \\
\text { Injury Rate }\end{array}$ \\
\hline Coal Operator & 2,063 & - & 78,281 & 87,184 & 19.5 & 3.5 \\
\hline Metal Operator & 263 & -- & 26,442 & 27,773 & 18.0 & 2.4 \\
\hline Nonmetal Operator & 739 & -- & 19,678 & 20,014 & 20.0 & 2.5 \\
\hline Stone Operator & 4,490 & -- & 69,759 & 73,650 & 20.4 & 3.1 \\
\hline Sand and Gravel Operator & 7,111 & -- & 37,705 & 34,258 & 26.3 & 2.5 \\
\hline Operator Total & 14,666 & -- & 231,865 & 242,879 & 20.6 & 3.0 \\
\hline Coal Contractor & -- & 2,503 & 32,639 & 20,136 & 24.8 & 2.7 \\
\hline Noncoal Contractor & -- & 4,297 & 46,623 & 25,590 & 7.8 & 1.6 \\
\hline Contractor Total & -- & 6,800 & 79,262 & 45,726 & 15.3 & 2.1 \\
\hline TOTAL & & & 311,127 & 288,605 & 19.8 & 2.9 \\
\hline
\end{tabular}

Fatality rates were computed per 100,000 FTE employees. Nonfatal lost-time injury rates were computed per 100 FTE employees.

Data source: Publicly released files of employment and accident/injury/illness data collected by MSHA under 30 CFR 50.

Notes: All analyses exclude office employees, except for the total number of mining operations. Analyses of fatalities exclude all individuals under 17 years of age and all individuals who were not classified as employees of a mining operator or mining contractor. Further statistical methodology is available on the NIOSH Internet [http://www.cdc.gov/niosh/mining/statistics/method.htm]. ${ }^{1}$ Number of employees is the average number of persons working at individual establishments during calendar quarters of active ope rations.

${ }^{2}$ Full-time equivalent employees were computed using reported employee hours $(2,000$ hours $=1 \mathrm{FTE})$.

${ }^{3}$ Mining sectors: coal operators, metal operators, nonmetal operators, stone operators, sand and gravel operators, coal contractors, and no ncoal contractors.

${ }^{4}$ Surface work locations include surface operations at underground mines (surface shops and yards, tipple physically located at the mine site), surface operations (strip or open pit mines including associated shops and yards), dredge (mining operations conducted from a platform floating on water), other surface operations (brine pumping, etc.), independent shops and yards not associated with a specific mine, and mill or preparation plant.

${ }^{5}$ Includes actual days away from work and/or days of restricted work activity. For permanently disabling injuries only, statutory days charged by MSHA were used if they exceeded the total lost workdays.

To receive NIOSH documents or for more information about occupational safety and health topics, contact $\mathrm{NIOSH}$ at 1-800-CDC-INFO (1-800-232-4636)

1-888-232-6348 (TTY)

e-mail: cdcinfo@cdc.gov

or visit the NIOSH Web site at http://www.cdc.gov/niosh

DHHS (NIOSH) Publication No. 2008-151 